Article

\title{
Sustainability Is All about Values: The Challenges of Considering Moral and Benefit Values in Business Model Decisions
}

\author{
Ivan Bolis ${ }^{1, *}$, Sandra Naomi Morioka ${ }^{2}$ (D), Wilza Karla dos Santos Leite ${ }^{1}$ and Paulo César Zambroni-de-Souza ${ }^{1}$ (D) \\ 1 Psychology Department, Federal University of Paraiba, João Pessoa 58051-900, Brazil; \\ wilzakarlas@yahoo.com.br (W.K.d.S.L.); paulozamsouza@yahoo.com.br (P.C.Z.-d.-S.) \\ 2 Production Engineering Department, Federal University of Paraiba, João Pessoa 58051-900, Brazil; \\ sandra.morioka@academico.ufpb.br \\ * Correspondence: bolis.ivan@alumni.usp.br; Tel.: +55-11-95366-7610
}

Citation: Bolis, I.; Morioka, S.N.; Leite, W.K.d.S.; Zambroni-de-Souza, P.C. Sustainability Is All about Values: The Challenges of Considering Moral and Benefit Values in Business Model Decisions. Sustainability 2021, 13, 664 https://doi.org/10.3390/su13020664

Received: 18 September 2020 Accepted: 25 November 2020 Published: 12 January 2021

Publisher's Note: MDPI stays neutral with regard to jurisdictional clai$\mathrm{ms}$ in published maps and institutional affiliations.

Copyright: (C) 2021 by the authors. Licensee MDPI, Basel, Switzerland. This article is an open access article distributed under the terms and conditions of the Creative Commons Attribution (CC BY) license (https:// creativecommons.org/licenses/by/ $4.0 /)$.

\begin{abstract}
Despite indications in the literature about the existence of win-win business opportunities regarding sustainability, most companies are still producing limited social and environmental results that are disconnected from their value propositions. Studies on the rationales underlying decisions regarding sustainability can offer a better understanding of this challenge. In particular, substantive rationality suggests that the decision-making process consider collective values for sustainability. This study investigates the following research question: What are the main challenges of making business decisions based on moral values of sustainable development? Using strategic decisions as a unit of analysis, action research in a start-up environment identified the following business challenges: (1) recognizing the limits of applying the moral values of sustainable development to the current business context dominated by maximization of economic and financial benefit values; (2) recognizing the normative nature of sustainability goals, which implies that moral values related to sustainable development are still external and not naturally occurring in people's personal moral values; (3) addressing conflicts between moral and benefit values and between collective and individual goals when including substantive rationality in business decisions; (4) engaging business stakeholders according to their personal moral values, as people are value driven; and (5) engaging workers in sustainable development values, as they play a central role in enabling benefit value creation for sustainable development. The paper offers interesting insights into moral value and benefit value. The former is the basis for individual decisions, while the latter represents benefits created by business models. Both concepts have been separately investigated, but this research delimits and differentiates them. Future studies can further investigate decision rationalities to enable sustainability in practice, as this is usually a theoretical discussion. Research on other start-ups and more mature organizations can also provide interesting insights.
\end{abstract}

Keywords: moral values; benefit values; start-up; action research; sustainable development; rationalities; decision-making process; corporate sustainability; business model

\section{Introduction and Background}

Humans are a central subject regarding sustainability [1]. Not only are people the beneficiary of more sustainable development, but they are also the active agent promoting, or not, this type of development. People can make decisions that have a decisive impact (positive or negative) on the future of humanity. Decisions are made by people and can affect the individual sphere or, with different degrees of impact, the collective sphere (regardless of whether such decisions are made within formal or informal organizations). Decisions may be conscious or not, but each has an impact (of different magnitudes, positive or negative) on the future development of humanity. The importance of decisions is also recognized in international discussions promoted by the United Nations (UN). The UN Agenda 2030 
proposed 17 sustainable development goals (SDGs) and 169 associated targets to guide the decisions we make over the next several years [2]. In this context, the type of rationality adopted to make decisions can affect people's actions and provide results that support or are contrary to global sustainable development and, therefore, the SDGs [3]. Instrumental rationality is related to social actions based on a means-ends rational calculation $[4,5]$. This kind of rationality, which dominates the current economic system [6], is the basis for the implementation of win-win business opportunities, providing both financial gains and positive social-environmental impacts. However, win-win situations do not always occur, and win-lose situations are also faced by decision makers, showing the limitation of instrumental rationality, which does not seem capable of providing sustainable development on its own. In particular, instrumental rationality shows limitations in the marketplace [7,8], especially when the main goal is maximization of financial gain $[9,10]$. There are proposals to consider the natural environment within instrumental rationality [11], but, in general, adding other types of rationalities into the decision-making processes can provide more sustainable development [3]. Substantive rationality $[4,5]$ based on ethical standards not directly related to the results can lead to moral, value-oriented, rational action and decisions for sustainable development. In recent years, some authors have called this rationality connected to sustainability "aesthetic rationality" [12,13] or "axiological rationality" [1]. This kind of rationality proposes a shift from rationality centered on individual interests (prevalent in the current economic system) to rationality centered on collective interests (prevalent in development based on human well-being) [1]. To make this shift effective, people need to make decisions that orient their actions guided by moral values toward more sustainable development. Moral values can be personal emotional dispositions or moral concepts, reasoning, properties, or rules, linked to concern for others [14]. Contributions at the end of the last millennium already pointed out the importance to recognize that environmental problems are an ethical, as much as an institutional, issue [15]. For example, the "full value" of an environmental resource is recognized not only in economic terms, but is largely based on subjective moral values and qualitative assertion [16]. Coming to more recent studies and broadening the view from environmental to a wider understanding of sustainable development, sustainability is recognized as a moral value related especially to intergenerational justice [17]. Other rationalities, in addition to the substantive rationality, have also been identified as valuable complements to the instrumental rationality for purposes of enabling sustainable development. Communicative rationality $[18,19]$ can promote cooperation and coordination for more sustainable decisions. Bounded rationality [20] permits the decision maker to consider human cognitive limits and the presence of complexities intrinsic to sustainable development [3]. Finally, phatic rationality considers the subjective question of decision making linked to psychoanalytic anthropology [21,22]. Despite these indications, the present research focused on substantive rationality, given its moral values-based approach, which has strong opportunity to support sustainable development solution implementation.

Companies and organizations are among the social spaces with the greatest potential to provide more sustainable future development. Because of the size of economic activities involved, each decision and each improvement introduced in companies and organizations can generate major positive (or negative) impacts on the natural, economic, and social environment. Concerns about sustainable development can be inserted through corporate sustainability policies [23]. Associated with concepts, such as TBL (triple bottom line) [24], sweet spot [25], and shared values [26], corporate sustainability implementors recognize that actions that benefit the natural environment or society can be aligned with the specific economic and financial interests of organizations. This recognition follows a decision-making approach based on instrumental rationality. Corporate sustainability includes encouraging organizations to exchange sustainable benefit value with their stakeholders [27], e.g., to take care of stakeholders' interests and needs and at the same time consider the stakeholders' contributions to the business model [28]. Considering stakeholders in business decisions can contribute to a strategic competitive advantage, cor- 
porate performance, and long-term business success [29]. Regarding the implementation of corporate strategy, business models can be described by three components: (1) their value proposition, (2) their value creation and delivery system, and (3) the value captured [30]. This description reflects the logic of strategic thinking about value [30]. By introducing more sustainable business models, companies are driven to propose, create, and deliver economic, environmental, and/or social value for their stakeholders [27,31]. In this context, value indicates the stakeholders' perception of certain benefits (utilities) to satisfy their needs, which can be created by an organizational business model [31]. Organizations can also destroy value [32] when they do not meet their stakeholders' needs or fail to satisfy them or create value that is not aligned with the stakeholders' worldview [33]. To refer to this type of value associated with business models, the present paper uses the term "benefit value".

Decision making to promote more sustainable businesses is currently a topic quite explored in the academic literature. The main applications in organizations are linked to the development of sustainability assessment tools [34,35] based on multi-criteria assessments [36-38], multi-attribute assessments [39], multi-objective assessments [40], etc. This literature suggests how decisions in organizations can be directed toward greater sustainability based on certain approaches [41], modules [42], models [43,44], concepts [45], methods [46], etc. These studies present a strategic bias, where the best advances in sustainability science are investigated to prescribe which aspects of sustainability should be considered in decisions. The present research, on the other hand, did not discuss specific decision criteria but attempted to introduce a more abstract level, which is the rationality used for decision-making. This rationality represents a general guideline for decisions, as it influences the decision criteria themselves. As discussed above, in general, the literature has investigated decision making to promote more sustainable businesses guided by a defined number of criteria, attributes, or objectives implemented in a top-down approach and with a means-ends rational calculation similar to instrumental rationality. There is, however, a gap in the literature, which takes little account of other types of decision rationalities. These rationalities tend to be more subjective and tacit, making it more difficult to create explicit units of analysis for academic research. In particular, there are still research opportunities to explore the role of people (workers at all hierarchical levels in organizations) in this decision-making process toward sustainable development. They are the subjects in the organization that make decisions. As suggested by the discipline of ergonomics, organizations can prescribe what workers should do or how they should make decisions, but what the workers actually do or decide is not necessarily what was previously prescribed $[47,48]$. Although workers can direct their decisions with instrumental rationality in line with the organization's objectives, they are not machines. Each worker has a subjective dimension, and decisions are made based on a cognitive decision-making process. The type of rationality used is specific to each worker and can be more or less instrumental, substantive, communicative, and limited. When they use substantive rationality, moral values guide their decisions and actions. These types of values can lead to strategies with superior value creation and value capture potential [49]. They differ from "benefit value", which addresses the value created (or destroyed) by organizations for their stakeholders, as discussed previously regarding sustainable business models.

Organizational decisions depend on not only prescribed criteria, attributes, or objectives, but also each stakeholder's worldview and moral values [33]. Starting from the outputs of a theoretical literature review about rationalities in the sustainable development context [3], the general hypothesis is that rationalities other than instrumental rationality need to be introduced in decision-making processes to promote additional actions concerning more sustainable development. In particular, the present research addresses the argument that decisions based on substantive rationality and aligned with the moral values of sustainable development could be essential. In other words, companies should engage in actions that provide greater corporate sustainability through decisions made based on the moral values linked to sustainable development. These moral values are 
associated with a more collective and axiological perspective on achieving sustainable development [1] and can include the following: (1) economic value as a means and not as an end, (2) quality of life, (3) altruism and sense of community, and (4) respect for the natural environment [3]. However, considering these moral values in decision making is not an easy and straightforward process. Therefore, this study investigated the following research question: What are the main challenges of making business decisions based on moral values of sustainable development?

\section{Materials and Methods}

The research question calls for an empirical investigation of an organization that makes decisions using a substantive rationality based on the moral values of sustainable development. To choose the best methodology, it was necessary to consider the following limitations. (1) The rationalities used by workers to make decisions in their organizations cannot be observed, and it is difficult to gather evidence of those rationalities in an interview process. (2) There are limitations in "managing" the decision rationality used by the researched organization. It would take time and training, and the use of a substantive rationality would still not be verifiable. (3) The main goal of the research was to analyze decisions that would have an impact on company sustainability output. In general, company executive directors are reluctant to be involved in academic research and would not be open to modifying the way they make their decisions.

Based on these limitations, the methodology selected for this research was action research implemented in the early stages of the development of a start-up and led by one of the researchers. Action research is seen as "a phenomenological methodological paradigm for carrying out research into management and organizations" [50]. This is a type of social research that is designed to be carried out in close association with practical actions but in which the researcher actively participates in cooperation with other social actors to solve a collective problem $[51,52]$. This active participation in organizational environments implies not only the physical presence of the researcher but also his or her contribution to active change through interventions that influence people and practices [53]. The proposal is that this type of research favors the changes and the processes of social emancipation [51], where the researcher is an agent of change and reality transformation [54]. The action research was applied in a start-up environment because it enabled the researchers to actively play a role in the decision-making process of a business that will be engaged in the market.

Experimenting and acting within organizational situations without being guided by a deductive framework allows the researcher to have a deep and rich understanding of the researched phenomena [55-57]. This type of methodology has already been applied in research related to the theme of sustainability with good results [58]. Action research is developed by a cyclical or spiral process that moves from planning to action to evaluation reflection [59]. In the present research, circles were developed, each comprising three phases: (1) understanding the context and purpose; (2) gathering, reporting, and analysing data and planning, implementing, and evaluating action; and (3) monitoring [60].

Literature suggest that action research can be applied in organizational development and can be design by the researcher to investigate specific situations [61]. For this, the cyclical processes of the present research were conducted considering strategic decisions as the unit of analysis. Operational decisions were also made during the start-up development, but, methodologically, it was not possible to consider them as a unit of analysis of the action research. Analyzing this large number of operational decisions was not suitable for the present research design. Only the main researcher had prior experiences regarding entrepreneurship, having cultivated skills related to business development. For this reason, only the main researcher was involved in the practical action of building the start-up. His role in the start-up was of the principal entrepreneur leading the action and the start-up team and making strategic decisions. In parallel with the practical development of the startup, for 11 months a continuous process of reflection and learning (that is, action research circles) was established, as advised by Coughlan and Coghlan [60]. Periodic meetings 
were held, particularly when each strategic decision was to be made. The first meeting was held to discuss the context and purpose of the research. The following meetings were structured to provide information about the practical development of the start-up. These discussions were important for creating space for reflections and served as input for each action research cycle.

For the purpose of the research, an attempt was made to base all decisions on a long-term and collective perspective that considers the four macro (moral) values of sustainable development. These macro values were chosen because they were the results of a comprehensive literature review about rationalities for sustainable development [3] in line with the concepts presented in this study. They are as follows:

(1) Economic value as a means and not an end. The objective of the start-up was to generate economic value (wages) for all components of the group (with the exception of the researcher) in line with market values. The start-up also tried to create more economic value to other stakeholders involved in the process. However, the maximization of economic value should not become the main motivation for start-up actions.

(2) Quality of life. In a broad view, there was a focus on creating more possible benefit value to all stakeholders that could generate more quality for their lives. However, the most prominent actions in this direction were developed inside the team.

(3) Altruism and sense of community. The mantra of all decisions was, "We need to think about how we can create more value (economic, social, environmental) for all stakeholders involved in the project before our financial gain". The main idea is to spread collaborations and altruism through the business and make the world better.

(4) Respect for the natural environment. This did not receive much priority because of the lack of aspects of environmental sustainability in the project.

While the research was developed in the action research model, the parallel development of the start-up was mainly based on the concept of a lean start-up [62,63]. In the beginning, design thinking tools and Lean Canvas were used, but the choice of the most promising ideas was developed mainly using the Lean Start-up Machine methodology. Applied in up to two days, this methodology allowed us to define from the direct contact with potential "customers" what their real needs were and how much benefit value the proposed solution had for them (e.g., asking at the end of the contact for some type of reward, such as money or contacts).

\section{Results}

The action research was conducted over 11 months in the context of an emerging economy, where social vulnerabilities are more present than in developed countries. The research was conducted in Brazil in the city of São Paulo. More specifically, the start-up development was influenced by the context of a large public university given the formal connection of the researcher-leader of the start-up as a researcher in the university's production engineering department. The action research comprised the stages described in Table 1. 
Table 1. Main results of the action research.

\begin{tabular}{|c|c|c|c|c|c|c|c|c|c|}
\hline \multirow{2}{*}{ Stage } & \multicolumn{3}{|c|}{ Decision-Making Process } & \multirow{2}{*}{$\begin{array}{l}\text { Associated Operational } \\
\text { Activities }\end{array}$} & \multicolumn{4}{|c|}{$\mathbf{S V}^{1}$} & \multirow[b]{2}{*}{$\begin{array}{l}\text { Lessons Learned and Limitations for } \\
\text { Sustainability }\end{array}$} \\
\hline & Decision & Mai & Decision Drivers & & 1 & 2 & 3 & 4 & \\
\hline $\begin{array}{l}\text { A-Search for } \\
\text { ideas }\end{array}$ & $\begin{array}{l}\text { What ideas for sustainable } \\
\text { development could be explored? }\end{array}$ & \multicolumn{2}{|c|}{$\begin{array}{l}\text { Social and/or environmental needs in the context of } \\
\text { specific regional development in Brazil. }\end{array}$} & $\begin{array}{l}\text { Application of the Lean } \\
\text { Startup Machine } \\
\text { methodology. }\end{array}$ & $x^{2}$ & $x$ & $\mathrm{x}$ & $x$ & $\begin{array}{l}\text { There are many socioenvironmental problems. } \\
\text { The entrepreneurship movement could gain } \\
\text { relevance in this context by trying to solve or } \\
\text { soften them. }\end{array}$ \\
\hline B-Ideas selection & $\begin{array}{c}\text { What three alternatives for this } \\
\text { new startup seem to be most } \\
\text { promising? }\end{array}$ & Greater rew & rd for potential customers. & $\begin{array}{l}\text { Analyse the three } \\
\text { selected ideas in more } \\
\text { detail and start } \\
\text { composing the teams for } \\
\text { each idea. }\end{array}$ & $x$ & $\mathrm{x}$ & & & $\begin{array}{l}\text { Companies can solve socioenvironmental needs } \\
\text { when developing products, services or } \\
\text { processes. However, these solutions must } \\
\text { necessarily create a value benefit for potential } \\
\text { customers. Without this, socioenvironmental } \\
\text { needs cannot be solved. }\end{array}$ \\
\hline \multirow[t]{2}{*}{$\begin{array}{l}\text { C-Choosing the } \\
\text { best idea to } \\
\text { develop }\end{array}$} & \multirow[t]{2}{*}{$\begin{array}{l}\text { Who will be part of the project } \\
\text { team? } \\
\text { What alternative will be } \\
\text { followed? }\end{array}$} & \multicolumn{2}{|c|}{ The presence of a cohesive team of entrepreneurs. } & $\begin{array}{l}\text { Finalize the composition } \\
\text { of the teams. }\end{array}$ & $\mathrm{X}$ & $\mathrm{x}$ & $\mathrm{x}$ & & $\begin{array}{l}\text { Importance of building a startup with } \\
\text { optimized knowledge to deal with the } \\
\text { challenges of building a business. In this } \\
\text { context, it seemed that aligning the values of } \\
\text { the team members with those of sustainability } \\
\text { is preferred but not necessary at the beginning. }\end{array}$ \\
\hline & & \multicolumn{2}{|c|}{$\begin{array}{l}\text { Potential customers must give economic benefit value } \\
\text { to the proposed solution. }\end{array}$} & $\begin{array}{l}\text { Focus on analysing the } \\
\text { revenue for each idea. }\end{array}$ & $\mathrm{x}$ & & & & $\begin{array}{l}\text { Regardless of the moral values that motivated } \\
\text { the development of a startup, this can become a } \\
\text { company only by creating economic value for } \\
\text { its internal stakeholders (and customers). }\end{array}$ \\
\hline \multirow{3}{*}{$\begin{array}{l}\text { D-Development } \\
\text { of the chosen } \\
\text { startup idea }\end{array}$} & \multirow{3}{*}{$\begin{array}{l}\text { What are the basic premises for } \\
\text { the new startup (value } \\
\text { proposition, clients and initial } \\
\text { practical knowledge)? }\end{array}$} & $\begin{array}{l}\text { (i) To delimit the } \\
\text { value proposition. }\end{array}$ & $\begin{array}{l}\text { It is necessary to highlight the } \\
\text { benefit value created. }\end{array}$ & $\begin{array}{l}\text { Participate in startup } \\
\text { contests to consolidate } \\
\text { the chosen startup idea. }\end{array}$ & $\mathrm{X}$ & $\mathrm{x}$ & $\mathrm{x}$ & & \multirow{2}{*}{$\begin{array}{l}\text { In the market environment, the priority is to } \\
\text { create economic and financial benefit value. } \\
\text { Although contact with customers is focused on } \\
\text { improving their quality of life, in the } \\
\text { development of a startup this should always be } \\
\text { measured in economic terms. Focusing on } \\
\text { sustainability values can create some } \\
\text { opportunity, or sometimes it cannot. }\end{array}$} \\
\hline & & $\begin{array}{l}\text { (ii) To investigate } \\
\text { more about the } \\
\text { needs of potential } \\
\text { customers. }\end{array}$ & $\begin{array}{l}\text { Search for information that could } \\
\text { create more value for } \\
\text { sustainability. }\end{array}$ & $\begin{array}{l}\text { Develop more } \\
\text { interviews with } \\
\text { potential customers. }\end{array}$ & $\mathrm{x}$ & $x$ & $\mathrm{x}$ & & \\
\hline & & $\begin{array}{l}\text { (iii) To seek } \\
\text { opportunities to } \\
\text { increase practical } \\
\text { knowledge. }\end{array}$ & $\begin{array}{l}\text { Search for situations to provide } \\
\text { the services to accumulate } \\
\text { knowledge about the startup } \\
\text { idea. }\end{array}$ & $\begin{array}{l}\text { Cover the need for } \\
\text { medical appointments } \\
\text { for students due to the } \\
\text { closure of this activity } \\
\text { previously offered for } \\
\text { free by the university. }\end{array}$ & $\mathrm{x}$ & & & & $\begin{array}{c}\text { A startup must show the potential to create } \\
\text { economic and financial benefit value, regardless } \\
\text { of the connection or lack thereof with } \\
\text { sustainability. }\end{array}$ \\
\hline
\end{tabular}


Table 1. Cont.

\begin{tabular}{|c|c|c|c|c|c|c|c|c|}
\hline \multirow{2}{*}{ Stage } & \multicolumn{2}{|c|}{ Decision-Making Process } & \multirow{2}{*}{$\begin{array}{l}\text { Associated Operational } \\
\text { Activities }\end{array}$} & \multicolumn{4}{|c|}{ SV $^{1}$} & \multirow[b]{2}{*}{$\begin{array}{l}\text { Lessons Learned and Limitations for } \\
\text { Sustainability }\end{array}$} \\
\hline & Decision & Main Decision Drivers & & 1 & 2 & 3 & 4 & \\
\hline \multirow{4}{*}{$\begin{array}{l}\text { E-Service } \\
\text { preparation }\end{array}$} & \multirow{4}{*}{$\begin{array}{l}\text { What are the key strategic } \\
\text { guidelines for providing the } \\
\text { service? }\end{array}$} & Search for good medical consultations. & $\begin{array}{l}\text { Establish partnership with } \\
\text { newly graduated doctors. }\end{array}$ & & $x$ & $\mathrm{x}$ & & $\begin{array}{l}\text { The financial opportunity was good and the } \\
\text { alignment with some sustainability value was } \\
\text { good. That is why there was no problem with } \\
\text { this stakeholder. }\end{array}$ \\
\hline & & \multirow[t]{2}{*}{$\begin{array}{l}\text { Location of service considering potential clients } \\
\text { (university students—convenience and reduction of } \\
\text { transportation needs). }\end{array}$} & $\begin{array}{l}\text { Attempted partnership } \\
\text { with university was not } \\
\text { successful. }\end{array}$ & & & & & $\begin{array}{l}\text { There are social norms or rules that regulate } \\
\text { some relationships. Rules and norms can } \\
\text { sometimes hinder considerations of more } \\
\text { organic issues, such as that of sustainability. }\end{array}$ \\
\hline & & & $\begin{array}{l}\text { Manage political conflicts } \\
\text { to enable a partnership } \\
\text { with the student } \\
\text { association. }\end{array}$ & & $x$ & $\mathrm{x}$ & $\mathrm{x}$ & $\begin{array}{c}\text { There are beliefs, cultural aspects or political } \\
\text { orientations that move people to actions. If } \\
\text { sustainability is not a priority, it is necessary to } \\
\text { try to align with people's (benefit and moral) } \\
\text { values. }\end{array}$ \\
\hline & & $\begin{array}{l}\text { Creation of economic benefit value for the stakeholders } \\
\text { involved. }\end{array}$ & $\begin{array}{l}\text { Develop the service } \\
\text { prototype and operational } \\
\text { processes. }\end{array}$ & $x$ & $\mathrm{x}$ & & & $\begin{array}{l}\text { In their relationship with the market, customers } \\
\text { can give priority to any solution that } \\
\text { incorporates sustainability issues. Despite this, } \\
\text { the economic benefit value of the service must } \\
\text { be considered good for them. }\end{array}$ \\
\hline $\begin{array}{l}\text { F-Service } \\
\text { feasibility }\end{array}$ & $\begin{array}{l}\text { How can the startup build } \\
\text { collaboration with stakeholders } \\
\text { to enable the service? }\end{array}$ & Cooperation (based on sustainability values). & $\begin{array}{l}\text { Develop the relationship } \\
\text { with students-customers. }\end{array}$ & $\mathrm{X}$ & $\mathrm{X}$ & $\mathrm{x}$ & & $\begin{array}{l}\text { The relationship with the main stakeholders } \\
\text { (customers and team members) is built mainly } \\
\text { by creating benefit value for them. This benefit } \\
\text { value is subjective for each one involved and is } \\
\text { aligned with respective needs and moral values, } \\
\text { which are not always aligned with the values } \\
\text { proposed by sustainability. }\end{array}$ \\
\hline
\end{tabular}


Table 1. Cont.

\begin{tabular}{|c|c|c|c|c|c|c|c|c|}
\hline \multirow{2}{*}{ Stage } & \multicolumn{2}{|c|}{ Decision-Making Process } & \multirow{2}{*}{$\begin{array}{c}\text { Associated Operational } \\
\text { Activities }\end{array}$} & \multicolumn{4}{|c|}{ SV $^{1}$} & \multirow[b]{2}{*}{$\begin{array}{l}\text { Lessons Learned and Limitations for } \\
\text { Sustainability }\end{array}$} \\
\hline & Decision & Main Decision Drivers & & 1 & 2 & 3 & 4 & \\
\hline & & & $\begin{array}{l}\text { Develop the relationship } \\
\text { with team members. }\end{array}$ & $x$ & $\mathrm{x}$ & $\mathrm{X}$ & & \\
\hline & & & $\begin{array}{l}\text { Develop the relationship } \\
\text { with competitors. }\end{array}$ & & & & & $\begin{array}{l}\text { Competitiveness spirit, which is the basis of the } \\
\text { current economic system, has the potential to } \\
\text { create very specific and individualistic benefit } \\
\text { value, which can become opposed to the values } \\
\text { proposed by sustainable development. } \\
\text { Competitiveness can destroy benefit value for } \\
\text { sustainability. }\end{array}$ \\
\hline G-Next steps & $\begin{array}{l}\text { What are next steps for the } \\
\text { startup (expand or redesign the } \\
\text { business model)? }\end{array}$ & Market opportunities with good economic results. & $\begin{array}{l}\text { Analyse expanding the } \\
\text { service outside the } \\
\text { university, involving the } \\
\text { general population or } \\
\text { private companies. End of } \\
\text { the action search. }\end{array}$ & $x$ & $\mathrm{x}$ & $\mathrm{x}$ & & $\begin{array}{l}\text { The qualifying aspect is creating economic } \\
\text { benefit value. Sustainability is just to improve } \\
\text { the idea without necessarily being able to create } \\
\text { the value that had been expected. }\end{array}$ \\
\hline
\end{tabular}

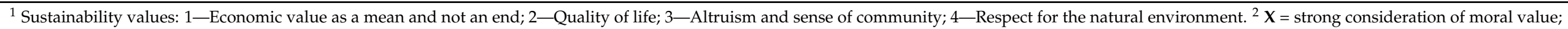
$\mathrm{x}=$ consideration of moral value 
In the first stage (A), the main decision was about which ideas to investigate. Based on the four macro sustainability values, some social and environmental needs were investigated in the context of specific regional development in Brazil. To investigate the potential customer needs, they were analyzed according to the Lean Start-up Machine methodology. In this first stage, it was possible to observe that there are many social and environmental problems in the Brazilian context that should be solved. A start-up, that is, a company that wants to put itself on the market, can start its activities by investigating and trying to solve socioenvironmental problems contributing to sustainable development. There are many demands.

In the second stage (B), three ideas with the greatest potential for start-up development were selected. The main decision made at this stage was related to the decision drivers to select the three ideas. Considering that the ideas could be aligned with the macro values of sustainability, the most relevant decision driver was to select the ideas that present the best preliminary solution for its potential customers. This is one of the fundamentals of developing a start-up: solving a strong "pain point" for a specific customer niche. Thus, the most popular reward ideas were chosen, mainly, cash contributions, evaluated through the Lean Start-up Machine cycles. In this second stage, the importance of evaluating the benefit value perceived by potential customers about the proposed solutions was observed. Ideas far from the customers' immediate needs received less interest.

There were interesting solutions to relevant socioenvironmental problems (e.g., the large concentration of plastic in the oceans), but these did not create enough benefit value because they were far removed from the immediate reality of people. After choosing the three ideas, they were analyzed in greater detail, and people interested in joining the entrepreneurs' team for each idea were chosen.

In the third stage $(C)$, the idea to be developed by the start-up was selected. The chosen start-up idea was inserted into the field of healthcare and had the social purpose of helping the lower income population of São Paulo city take care of their own health at a cheaper price. The basic idea was to build a marketplace between people with similar medical needs (e.g., dermatology, gynecology, and ophthalmology) and newly graduated doctors. Through an optimization of the doctor's time and an optimization of the appointment schedule, the objective was to significantly reduce the price of private medical consultations in Brazil. The initial team behind this idea was composed of the main researcher and two other individuals. The choice was made mainly based on two points: (1) the presence of a cohesive team and (2) the potential economic value granted by customers regarding the idea. Although the decision should have been based on all sustainability values, there was a need to make the "economic value as a mean and not an end" value predominant. When building a start-up, it is essential to create economic benefit value. With no cash inflows, the start-up is bound to fail. Additionally, in the evaluation of the teams, an attempt was made to choose the team whose moral values were aligned with those of sustainability. However, it was first necessary to choose the team who had the skills to deal with the challenges of building a business.

In the fourth stage (D), the chosen business idea was developed. The complementary directions for this stage were (1) to consolidate and structure the idea by participating in events and contests connected to the start-up, (2) to investigate with more detail the needs of potential customers, and (3) to look for practical opportunities to begin the start-up actions in the market. The first two points reinforced what had been discussed previously: The idea that has a sustainability bias is looked upon positively (especially if it is aligned with the moral or benefit values of those who were evaluating the business idea). However, the most important aspect is that the proposed solution meets some need that is felt strongly by potential customers and, as a result, can generate economic benefit value. In relation to the search for practical opportunities (3), it was discovered that the free outpatient care service at the university hospital was closed, which caused many problems for low-income students. Solving this problem and offering an alternative service was considered an interesting opportunity. 
The fifth stage (E) consists of making the service to attend the opportunity found at the university feasible. Some decisions were made regarding how the service should be developed: (1) It should be of the highest possible quality, (2) it should be developed locally (specifically, the location of greatest student concentration at the university) to reduce the dislocation of students in the city, and (3) it should be structured to offer prices lower than half of those that were being charged in the most economical private initiatives in the city of São Paulo. The first two decisions allowed us to meet the moral values "respect for the natural environment" and "quality of life" of the students. The third decision was ambitious because the objective was to create economic benefit value for the main stakeholders (customers and health professionals), considering that this created trade-offs with the creation of economic benefit value for the start-up. To operationalize the decisions of this stage (E), it was necessary to develop partnerships with different stakeholders based on the moral value of "altruism and sense of community". There were three more significant cases. The first partnership was with newly trained doctors to provide the service. This partnership was relatively simple to establish because the doctors could achieve economic gains and help a population (students) with whom they still identify. The second case of partnership was with the university administration. Although the social objective of the start-up was clear, the university did not give formal support for start-up development within the university for bureaucratic reasons. Economic activities within the university cannot be formally accepted if they do not go through a bidding process. The third case was student associations. Without formal university support, they were the alternative to find spaces inside the university to develop the action. Contacts with student associations lasted two months until they accepted a partnership. The delay was caused by two motivations. First, it was noticed that they had issues they considered more relevant, such as managing the progress of a strike within the university. The second was caused by the presence of different ideological groups of students. Although the benefit for the students was clear, and the idea received support from the most representative student group, political issues and rivalries caused opposition groups to not give support to the start-up. To overcome this problem, it was necessary to reinforce the independence of the action in relation to student groups, to reinforce the benefits of the action, and to create bonds with the opposition groups. In this stage, in addition to the listed decisions, the entrepreneurship group developed other operational actions and processes, such as creating the service prototype.

With the acceptance of student associations to lend a well-located physical place within the university for medical assistance, the sixth stage (F) began. In this stage, medical consultations were offered to students. In three months, more than 400 consultations were made. The initial idea of condensing all consultations into blocks of 3-4 h, scheduled depending on the demand for the service (the blocks could be, for example, after two days or after a week) and with appointments scheduled at intervals of $15 \mathrm{~min}$, worked well and was maintained throughout the period. There are some interesting considerations from this period in relation to (1) student-clients, (2) start-up team members, and (3) a competitor. In relation to student-clients, the team's effort was totally directed toward improving the service provided, especially in dermatology service, and focusing on maximizing the creation of benefit value according to the start-up proposal. On a few occasions, the start-up faced the trade-off of deciding to attend to students on Saturday, even if the low number of students on this day of the week was not economically convenient. Considering the moral values of the research, the start-up tried to meet these specific needs, a different behavior than what a traditional start-up would have done. Student feedback was positive, with some spontaneously praising the team for their actions. In relation to the start-up team, in this period, another component was added to address the operational part. The moral values brought by the research allowed the action to be developed in a professional manner, creating bonds of collaboration and friendship between the team members. From the beginning, it was decided to focus on the motivation of the people who worked on the start-up, promoting a more collaborative, fun, and transparent business. In addition, based 
on the idea of the central role of work in people's lives, great attention was given to the health creation and to the human development of those team members. The only critical aspect that needed to be overcome was the economic aspect. The team members received economic compensation in line with their role, except for the researcher, who received no compensation. Even with these expenses, the service allowed profits. The question was whether to keep the remaining amount to be invested in the start-up in the future or to divide it among the team members. The decision was made to follow the first option, but it was clearly a win-lose decision. By giving the start-up an option to develop, the satisfaction of two team members was affected. In a start-up context, the choice could not be different. Despite this explicit alignment to moral values for sustainability, which can be considered positively in an initial discussion, conflicts or inconsistencies can be created regarding the personal needs of team members. It was confirmed that people follow more individual (moral and benefit) values than collective values. Regarding competition, at the end of the sixth stage (F), a student sports association decided to open a similar initiative. Most of the start-up medical appointment demand was derived from the need for medical certification to attest that they are able to perform physical activities in the university sports complex. With a better location, a good base of associates, the sole expense of hiring a doctor, and lowering the quality of the service, strong direct competition for the start-up service began. The decision was made to try to develop a partnership based on the moral value of "altruism and sense of community". It was observed that the competitive spirit of the sports association did not allow any progress. The service demand was limited. Dividing it between competitors meant dividing the economic benefit value from the service. Another interesting aspect observed was that students who did not receive medical certification from the start-up due to genuine health restrictions did receive one from the student association service provider. For students, having a service with "fewer problems" in receiving a medical certification seemed to be preferred. It was realized that the advances made by the start-up, especially in the quality of the service, were not something perceived as a benefit value by the student-clients. The students were not interested if their poor health could compromise the health of others. In addition, the physician who attended the competing service did not have attitudes aligned with the ethics expected for this professional class. This is another clear evidence of the preponderance of financial benefit value over other social value.

At the end of the action research, in the seventh stage $(G)$, the start-up team noticed a decrease in the number of consultations. In this stage, it was decided to open new niche markets with new customers. Therefore, the possibilities of expanding the service outside the university, involving the general population or private companies, were analyzed. In this case, it was observed that the qualifying aspect of the decisions was to find some solution that could be economically viable, while following the values of sustainability was more about improving the proposed solutions. It was at this point that action research was interrupted, while the start-up continued its development.

\section{Discussion}

The conducted action research brought a deeper understanding of the challenges of businesses that aim to increase their contribution to sustainable development. These arguments were organized into five challenges that start from a broad view on the market in which companies transact business to a specific aspect of work and workers in business models for sustainable development.

\subsection{Recognizing the Limits of Applying the Moral Values of Sustainable Development to the Current Business Context Dominated by Maximization of Economic and Financial Benefit Values}

The research provides empirical evidence that win-win solutions can be created between generating good business and creating social benefits for more sustainable development. However, in practice, companies are not always able to execute these intentions. For example, the analyzed start-up was built with the explicit objective of maximizing the contribution to society based on decisions driven by the moral values of sustainable 
development, but, in practice, the benefits were limited. As shown in Table 1, although substantive rationality has always been used, considering the four sustainable development moral values, decisions were made predominantly considering the values of "economic value as a mean and not an end" and "quality of life". Even these values were applied in a very reductionist way. The first was predominantly focused on the financial sustainability of the start-up and the second on meeting the needs of the closest stakeholders. The constant concern at all stages of the start-up was to create revenue for the start-up. This concern started from the moment of choosing the most promising ideas (stage B) to changing the strategy at the end of the action research (stage G). For a start-up engaging in the market, this aspect was important in creating an engaged team, participating in acceleration programs, attracting investors, expanding the business, etc. Analyzing the relationship with team members could help identify some personal motivations (friendship, interest in the project, etc.). However, to be involved in the long run, it was necessary to deliver economic benefit value. For example, the need to earn money to pay the bills each month was a key factor for the participation of at least two team members in the project.

Sustainable development and corporate sustainability seem to operate in different environments with different concerns. The beneficiary of sustainable development is humanity, that is, a community that is inserted into a natural environment with socioeconomic dynamics. The beneficiaries of corporate sustainability (or the application of sustainability in business) are companies, which are individual entities that are inserted into an environment that is not natural. If a business does not prioritize economic-financial aspects, it is almost certain that it will not develop and will not survive in the market (that is, the business environment). Therefore, for a business, the moral values of sustainable development can be considered after the creation of economic and financial benefit values.

These findings confirm the interdependence between socioenvironmental aspects and economic-financial goals when corporations implement sustainable actions and decisions in line with the concepts of the triple bottom line [24] and sweet spot [25]. These findings advance the literature by identifying different priorities between sustainable development (focused more on socioenvironmental aspects) and corporate sustainability (focused more on economic-financial aspects).

4.2. Recognizing the Normative Nature of Sustainability Goals, which Implies that Moral Values Related to Sustainable Development Are Still External and not Naturally Occurring in People's Personal Moral Values

The required economic-financial benefit value created by businesses that was mentioned in the previous discussion point is achieved mainly by creating socioeconomic benefit value for customers through products or services. This was one of the fundamental principles in building the analyzed start-up, which used the Lean Startup Machine methodology and the Lean Canvas [64].

Focusing attention on the stakeholders, the action research showed that a product or service (or partnership, etc.) delivers more socioeconomic benefit values when it satisfies individual needs in a specific moment. Moreover, it was observed that this socioeconomic benefit value is generally aligned with each stakeholder's individual moral values, mediated by their bounded rationality. For example, in stage F, when students preferred to receive a medical certification from a service with "fewer problems", their specific need at the time was to be able to access the university sports complex and swimming pool. Not compromising the health of other students (a form of altruism) was not one of their moral values, or it was but it was not taken into consideration in their decision because of bounded rationality.

In the context of sustainable development, stakeholders' decisions have to show a different logic. This type of development aims to create collective benefit value for the benefit of humanity. To achieve this objective, each person should make decisions aligned with specific moral values [3] recognizing the main needs of humanity and considering points of view different from their own (through communicative rationality). In other words, sustainable development proposes that stakeholders make decisions and act based 
on a set of moral values that can be considered "absolute". However, the present research suggests that stakeholders decide and act inside a context of bounded rationality and based on moral values that are various, individual-specific, and subjective. If people's moral values are not aligned with those of sustainability, it is difficult to achieve truly sustainable development. Furthermore, if stakeholders have moral values of sustainability among their moral values, in some contexts, they can make decisions giving priority to moral values not aligned with those of sustainability. In stages E and F, for example, the members of student associations could have had moral values of sustainability among their moral values, but they made decisions prioritizing the moral values of defending political principles and competitiveness.

Summarizing this point, these findings suggest that aligning individual moral values with those of sustainability is difficult because sustainability emerges as a normative goal [17]. During the development of the start-up, it was also observed that values related to sustainable development are still "external" and not always naturally occurring in people's personal moral values. In particular, the values "altruism and sense of community" and "respect for the natural environment" may be present, but they may not be a priority for people.

4.3. Addressing Conflicts between Moral and Benefit Values and between Collective and Individual Goals when Including Substantive Rationality in Business Decisions

While engaging in sustainable development is based on substantive rationality (based on defined moral values) and on creating collective benefit values, corporate sustainability is mainly subjugated to an instrumental rationality to create individual benefit value (mainly of an economic-financial nature for the company and of a socioeconomic nature for its stakeholders). This marked difference between the two development models causes some incompatibilities. A company can be successful in the current market whether it is creating or destroying collective social value. If a company is only concerned with creating a more collective benefit value, in many instances there may be no market for its actions. This is the case for the idea selection stage (Stage B). Some identified ideas had the ability to create abundant collective benefit value, but they were not aligned with the most urgent individual needs of potential customers. These ideas did not create benefit value for the interviewees and were, therefore, discarded.

The challenge for an organization that wants to include substantive rationality for sustainable development in its decision-making processes is to try to promote changes among their stakeholders. In particular, organizations need to try to align their moral and benefit values and those of their stakeholders with the values of sustainable development. Figure 1 shows that corporate sustainability depends on the organization's effort to influence internal and external stakeholders toward incorporating the sustainable development model values into the current development model mainly based on individual moral and benefit values. This consideration is novel in the literature and implies that the premises of sustainable development would suggest a change in the usual corporate approach, redefining even the interpretation of the meaning of benefit value [65]. 


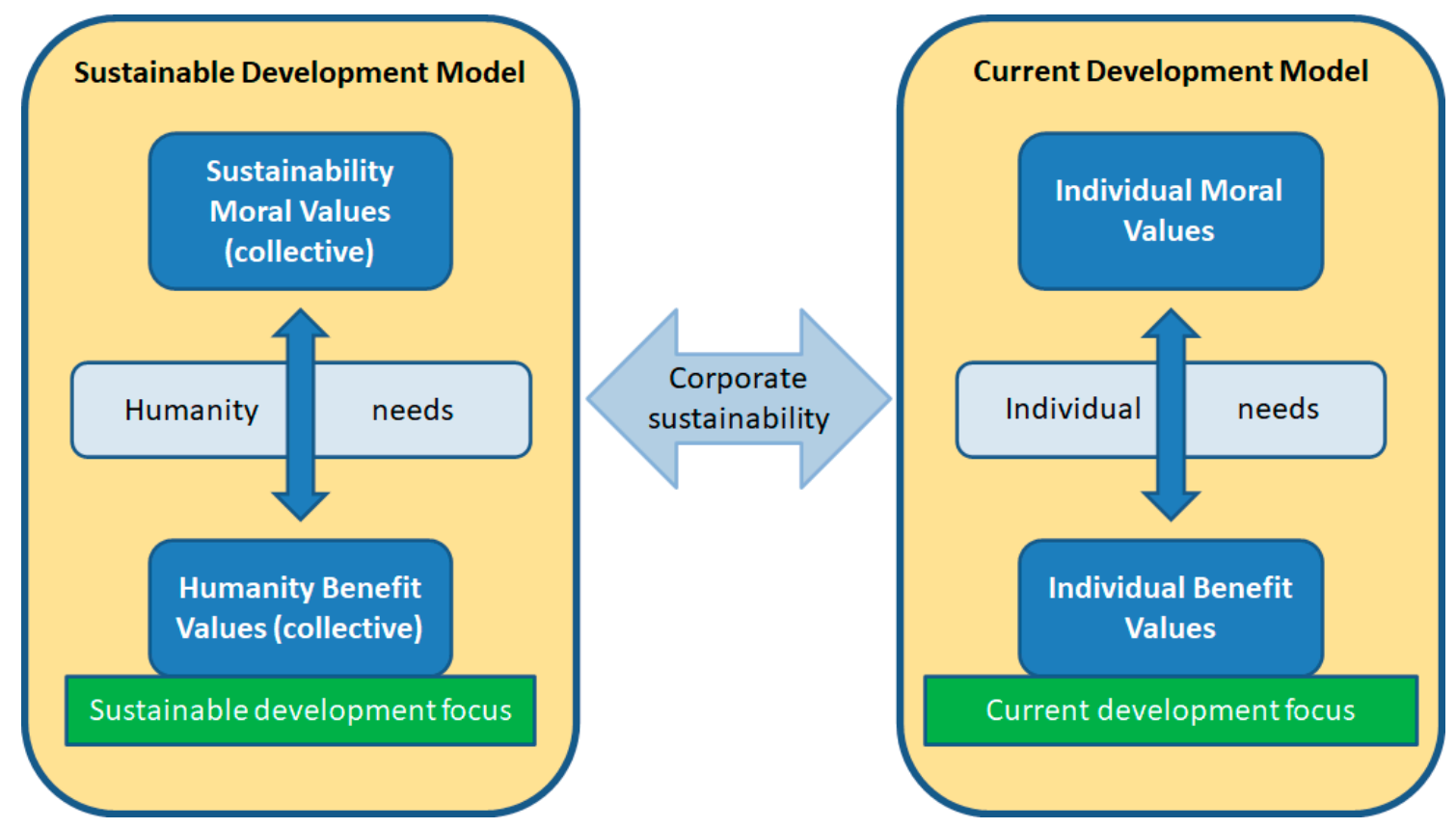

Figure 1. Relationship between sustainable development and current development values.

4.4. Engaging Business Stakeholders According to Their Personal Moral Values, as People Are Value Driven

Aligning the moral and benefit values of organizations and their stakeholders with those of sustainable development is not something that can be reduced to a simple management of two variables, specifically "type of value" (moral and benefit) and "beneficiary of the decision" (collectivity and individual). Organizations need to consider the human factor, which is very complex. There is a dominant culture based on capitalism, which is "directed towards making the greatest possible profits for successful organizations and people" [66], which reinforces individualism and instrumental rationality. Despite this, humans are not completely rational thinkers, and their decisions do not necessarily follow expected benefit theory [67]. The present action research showed that people act, sometimes more and sometimes less consciously, based on a series of personal moral values or beliefs such as friendship, making a difference, entrepreneurship, recognition, cooperation, etc. Educating people about sustainability values is advised [68] (considering subjective realities); however, the sustainability movement in organizations should engage their stakeholders from their existing personal moral values. Disseminating positive moral values on the basis of the concept of sustainable development and encouraging all stakeholders involved in considering their personal moral values can create opportunities for more sustainable development. For example, in the start-up experience, there was much positive feedback from customers and it was realized that the values of the initiative had influenced them and could be propagated even outside the established service relationship. In the literature, the role of moral values is already recognized as important in the development and acceptance of more sustainable solutions [69].

\subsection{Engaging Workers in Sustainable Development Values, as They Play a Central Role in Enabling Benefit Value Creation for Sustainable Development}

The action research shows the important position of workers in the process of including sustainability in organizations. These stakeholders direct which benefit value can be created. Workers can act at different hierarchical levels of organizations, make strategic decisions with macro organizational impacts, or make operational decisions with localized impacts. Giving an example from the start-up, the position of the main researcher as the start-up leader showed that including more substantive rationality can create more value 
in line with sustainable development. The moral values and personality of entrepreneurs are essential for a start-up to be engaged in developing corporate sustainability or related initiatives [70]. Additionally, the other members of the team directed their intelligence, creativity, skills, and abilities to create value for the company and sustainable development. The results included the development of the service (the creation of an economic alternative in health services for low-income students), the creation of a good team, the development of good relations with other stakeholders, the fulfillment of customer needs, etc. Having the presence of these values was extremely positive, allowing the creation of collaboration and value for all start-up project stakeholders. Companies that would like to include sustainability in their strategic objectives need to promote the spread of sustainability values among their workers and empower them. Likewise, workers can successively spread these values to other stakeholders as well, allowing the creation of an alignment between the moral values of sustainability and individuals and creating benefit value for stakeholders in line with sustainable development. This can allow the creation of new business opportunities. Promoting the centrality of workers in providing sustainability in organizations must be guided by a continuous alignment of values between people and the organization to avoid creating negative effects derived from possible gaps [71]. The importance of workers' decisions and actions in the context of sustainability is recognized implicitly by the literature, especially in ergonomics [72,73]. However, this research makes this finding explicit.

\section{Conclusions}

Indications for win-win opportunities by introducing environmental and social goals into economic goals are not recent, as previously pointed out by concepts such as TBL (Triple Bottom Line) [24], sweet spot [25], and shared values [26]. However, why are there still so many opportunities for possible social and environmental improvements in the corporate context? To better understand the limitations of these win-win solutions, the present research investigated rationalities for decisions for sustainability purposes in practice. In particular, substantive rationality can support sustainable development, as it evokes that the decision-making process should consider collective values for sustainability, e.g., (1) economic value as a means and not as an end, (2) quality of life, (3) altruism and sense of community, and (4) respect for the natural environment. Therefore, the present research addressed the following research question: What are the main challenges of making business decisions based on moral values of sustainable development? Using strategic decisions as a unit of analysis, action research in a start-up environment identified the following business challenges: (1) recognizing the limits of applying the moral values of sustainable development to the current business context dominated by maximization of economic and financial benefit values; (2) recognizing the normative nature of sustainability goals, which implies that moral values related to sustainable development are still external and not naturally occurring in people's personal moral values; (3) addressing conflicts between moral and benefit values and between collective and individual goals when including substantive rationality in business decisions; (4) engaging business stakeholders according to their personal moral values, as people are value driven; and (5) engaging workers in sustainable development values, as they play a central role in enabling benefit value creation for sustainable development.

The present research provides a better understanding of the challenges of incorporating sustainability in practice, presented in Section 4 in more detail. The research indicates that these challenges are derived from incompatibilities between moral and benefit value in different contexts that affect business decisions. Companies are engaged in the capitalist market and, therefore, are driven to create benefit value for their clients and, if possible, for other stakeholders. In turn, what these stakeholders assess as benefit value depends on their respective moral values, as these directly influence their needs and worldview. However, these moral values do not necessarily align with sustainable development. Therefore, the present action research showed that even if companies are led by individuals who 
make decisions based on a substantive rationality, e.g., based on values for sustainability, the alignment between the benefit value created by this organization and sustainable development depends on stakeholders' moral values.

Following this logic and the research question, the present research provides empirical evidence that using substantive rationality for strategic decisions has the potential to contribute to corporate sustainability, but this depends on company capacity to influence stakeholders' moral values in the direction of collective values for sustainable development.

This research differentiates itself from previous ones, as it explicitly differentiates moral values and benefit value. The first indicates what individuals find as important when making decisions, and the second represents benefits created by company business models. In addition, this research also makes explicit that both concepts are interrelated, as what individuals consider useful is moderated by what they value in their decisions. Both concepts have been separately used to support the corporate sustainability discussions, but this research innovates in using both to support advances in this knowledge.

Another relevance of the research lies in providing empirical evidence in a rather theoretical discussion of rationalities for decisions in the context of sustainable development and corporate sustainability. For this, it chose to use the strategic decision as the unit of analysis, offering a relatively clear outline for depicting the large challenge of applying corporate sustainability in practice. This choice enabled a clearer analysis of empirical data.

Research limitations can be drawn from the research design, as only one action study was conducted, and the time frame of data collection was relatively short. Limitations of access to data on other start-up design processes and for longer periods were mitigated by a deeper analysis of available data. Thus, future research is called for to further investigate rationalities for decisions toward sustainability in practice, as the present research brought indications of the potential contribution of this area of research. In particular, the challenges raised by the present research presented in Section 4 are open to further investigations on how to cope with them, mitigating their negative effects on the business. For this, research on other types of start-ups, as well as on organizations in other lifecycle stages with a longer maturity time in the market, can also provide interesting insights for this body of knowledge.

Author Contributions: I.B. and S.N.M. conceived conceptualization and designed the methodology. I.B. participated in start-up development. I.B., S.N.M., and W.K.d.S.L. performed data analysis and discussion. I.B., S.N.M., and W.K.d.S.L. participated in writing-review and editing. P.C.Z.d.-S. participated in supervision. All authors have read and agreed to the published version of the manuscript.

Funding: This research received no external funding.

Informed Consent Statement: Not applicable.

Data Availability Statement: Data is contained within the article.

Acknowledgments: The authors gratefully acknowledge the Federal University of Paraiba for its financial support regarding publication fees.

Conflicts of Interest: The authors declare no conflict of interest.

\section{References}

1. Bolis, I.; Morioka, S.N.; Sznelwar, L.I. When sustainable development risks losing its meaning. Delimiting the concept with a comprehensive literature review and a conceptual model. J. Clean. Prod. 2014, 83, 7-20. [CrossRef]

2. UN. Transforming Our World: The 2030 Agenda for Sustainable Development. Available online: https://www.un.org/ga/ search/view_doc.asp?symbol=A/RES/70/1\&Lang=E (accessed on 17 July 2020).

3. Bolis, I.; Morioka, S.N.; Sznelwar, L.I. Are we making decisions in a sustainable way? A comprehensive literature review about rationalities for sustainable development. J. Clean. Prod. 2017. [CrossRef]

4. Kalberg, S. Max Weber's types of rationality: Cornerstones for the analysis of rationalization process in history. Am. J. Sociol. 1980, 85, 1145-1179. [CrossRef]

5. Weber, M. Economy and Society; Roth, G., Wittich, C., Eds.; University of California Press: Berkeley, CA, USA, 1968.

6. Gallino, L. L'impresa Irresponsabile; Einaudi: Torino, Italy, 2005. 
7. Borges, H.B.; Fernandes, V. The use of asbestos in Brazil: The clash of two rationalities in the supreme federal court. Ambiente Soc. 2014, 17, 175-194. [CrossRef]

8. Reigner, H. Neoliberal Rationality and Neohygienist Morality. A Foucaldian Analysis of Safe and Sustainable Urban Transport Policies in France. Territ. Polit. Gov. 2016, 4, 196-215. [CrossRef]

9. Lemeilleur, S.; N'Dao, Y.; Ruf, F. The productivist rationality behind a sustainable certification process: Evidence from the Rainforest Alliance in the Ivorian cocoa sector. Int. J. Sustain. Dev. 2015, 18, 310-328. [CrossRef]

10. Fielke, S.J.; Wilson, G.A. Multifunctional intervention and market rationality in agricultural governance: A comparative study of England and South Australia. GeoJournal 2017, 82, 1067-1083. [CrossRef]

11. Hamilton, C. Consumerism, self-creation and prospects for a new ecological consciousness. J. Clean. Prod. 2010, 18, 571-575. [CrossRef]

12. Helth, P. Aesthetic-based competences lead to a sustainable learning practice: Re-thinking public management through the lens of sustainability. Local Econ. 2019, 34, 607-617. [CrossRef]

13. Shrivastava, P.; Schumacher, G.; Wasieleski, D.M.; Tasic, M. Aesthetic Rationality in Organizations: Toward Developing a Sensitivity for Sustainability. J. Appl. Behav. Sci. 2017, 53, 369-411. [CrossRef]

14. Bagozzi, R.P.; Sekerka, L.E.; Hill, V.; Sguera, F. The Role of Moral Values in Instigating Morally Responsible Decisions. J. Appl. Behav. Sci. 2013, 49, 69-94. [CrossRef]

15. Jenkins, T.N. Economics and the environment: A case of ethical neglect. Ecol. Econ. 1998, 26, 151-163. [CrossRef]

16. Buttoud, G. How can policy take into consideration the "full value" of forests? Land Use Policy 2000, 17, 169-175. [CrossRef]

17. Scarano, F.R. The emergence of sustainability. In Emergence and. Modularity in Life Sciences; Wegener, L., Lüttge, U., Eds.; Springer-Nature: Cham, Switzerland, 2019; pp. 51-71.

18. Habermas, J. The theory of communicative action. In Lifeworld and System: A Critique of Functionalist Reason; Beacon Press: Boston, MA, USA, 1989.

19. Habermas, J. The theory of communicative action. In Reason and the Rationalization of Society; Heinemann: London, UK, 1984; Volume 1.

20. Simon, H. Rationality in Psychology and Economics. J. Bus. 1986, 59, S209-S224. [CrossRef]

21. Dejours, C. Trabalho Vivo-Trabalho e Emancipação, 1st ed.; Paralelo 15: Brasilia, Brazil, 2012.

22. Hubault, F.; Sznelwar, L.I. Can activity be understood out of subjectivity? Work 2012, 41, 26-29. [CrossRef]

23. Dyllick, T.; Hockerts, K. Beyond the business case for corporate sustainability. Bus. Strateg. Environ. 2002, 11, 130-141. [CrossRef]

24. Elkington, J. Cannibals with Forks: The Triple Bottom Line of 21st Century Business; New Society Publishers: Oxford, UK, 1997.

25. Savitz, A.W.; Weber, K. The Sustainability Sweet Spot. Environ. Qual. Manag. 2007, 17, 17-28. [CrossRef]

26. Porter, M.E.; Kramer, M.R. Creating shared value. How to reinvent capitalism—and unleash a wave of innovation and growth. Harv. Bus. Rev. 2011, 89, 62-77.

27. Morioka, S.N.; Bolis, I.; Carvalho, M.M.D. From an ideal dream towards reality analysis: Proposing Sustainable Value Exchange Matrix (SVEM) from systematic literature review on sustainable business models and face validation. J. Clean. Prod. 2018, 178. [CrossRef]

28. Freudenreich, B.; Lüdeke-Freund, F.; Schaltegger, S. A Stakeholder Theory Perspective on Business Models: Value Creation for Sustainability. J. Bus. Ethics 2020, 166, 3-18. [CrossRef]

29. Freeman, R.E.; Mc Vea, J. A Stakeholder Approach to strategic management. In Handbook of Strategic Management; Hitt, M., Freeman, E., Harrison, J., Eds.; Blackwell Publishing: Oxford, UK, 2001; pp. 189-207. ISBN 0273019139.

30. Richardson, J. The business model: An integrative framework for strategy execution. Strateg. Chang. 2008, 17, 133-144. [CrossRef]

31. Evans, S.; Vladimirova, D.; Holgado, M.; Van Fossen, K.; Yang, M.; Silva, E.A.; Barlow, C.Y. Business Model Innovation for Sustainability: Towards a Unified Perspective for Creation of Sustainable Business Models. Bus. Strateg. Environ. 2017, 608, 597-608. [CrossRef]

32. Yang, M.; Vladimirova, D.; Evans, S. Creating and capturing value through sustainability: The Sustainable Value Analysis Tool. Res. Technol. Manag. 2017, 60, 30-39. [CrossRef]

33. Upward, A.; Jones, P. An Ontology for Strongly Sustainable Business Models: Defining an Enterprise Framework Compatible With Natural and Social Science. Organ. Environ. 2016, 29, 97-123. [CrossRef]

34. Tarne, P.; Lehmann, A.; Finkbeiner, M. Introducing weights to life cycle sustainability assessment-How do decision-makers weight sustainability dimensions? Int. J. Life Cycle Assess. 2019, 24, 530-542. [CrossRef]

35. Coteur, I.; Wustenberghs, H.; Debruyne, L.; Lauwers, L.; Marchand, F. How do current sustainability assessment tools support farmers' strategic decision making? Ecol. Indic. 2020, 114, 106298. [CrossRef]

36. Josa, I.; Pons, O.; De la Fuente, A.; Aguado, A. Multi-criteria decision-making model to assess the sustainability of girders and trusses: Case study for roofs of sports halls. J. Clean. Prod. 2020, 249, 119312. [CrossRef]

37. Zavadskas, E.K.; Pamučar, D.; Stević, Ž.; Mardani, A. Multi-Criteria Decision-Making Techniques for Improvement Sustainability Engineering Processes. Symmetry 2020, 12, 986. [CrossRef]

38. Sitorus, F.; Brito-Parada, P.R. A multiple criteria decision making method to weight the sustainability criteria of renewable energy technologies under uncertainty. Renew. Sustain. Energy Rev. 2020, 127, 109891. [CrossRef] 
39. Liu, J.; Fang, M.; Jin, F.; Wu, C.; Chen, H. Multi-attribute decision making based on stochastic DEA cross-efficiency with ordinal variable and its application to evaluation of banks' sustainable development. Sustainability 2020, 12, 2375. [CrossRef]

40. Marhavilas, P.K.; Tegas, M.G.; Koulinas, G.K.; Koulouriotis, D.E. A joint stochastic/deterministic process with multi-objective decision making risk-assessment framework for sustainable constructions engineering projects-A case study. Sustainability 2020, 12, 4280. [CrossRef]

41. Hendiani, S.; Mahmoudi, A.; Liao, H. A multi-stage multi-criteria hierarchical decision-making approach for sustainable supplier selection. Appl. Soft Comput. J. 2020, 94, 106456. [CrossRef]

42. García-Segura, T.; Montalbán-Domingo, L.; Sanz, M.A.; Lozano-Torró, A. Sustainable Decision-Making Module: Application to Public Procurement. J. Civ. Eng. Educ. 2020, 146, 1-11. [CrossRef]

43. Abdel-Basset, M.; Mohamed, R.; Sallam, K.; Elhoseny, M. A novel decision-making model for sustainable supply chain finance under uncertainty environment. J. Clean. Prod. 2020, 269, 122324. [CrossRef]

44. Rajesh, R. Sustainable supply chains in the Indian context: An integrative decision-making model. Technol. Soc. 2020, 61, 101230. [CrossRef]

45. Sedliačiková, M.; Aláč, P.; Moresová, M. How Behavioral Aspects Influence the Sustainable Financial Decisions of Shareholders: An Empirical Study and Proposal for a Relevant Decision-Making Concept. Sustainability 2020, 12, 4813. [CrossRef]

46. Rasheed, R.; Javed, H.; Rizwan, A.; Yasar, A.; Tabinda, A.B.; Mahfooz, Y.; Wang, Y.; Su, Y. Sustainability and CDM potential analysis of a novel vs conventional bioenergy projects in South Asia by multi-criteria decision-making method. Environ. Sci. Pollut. Res. 2020, 27, 23081-23093. [CrossRef]

47. Daniellou, F.; Rabardel, P. Activity-oriented approaches to ergonomics: Some traditions and communities. Theor. Issues Ergon. Sci. 2005, 6, 353-357. [CrossRef]

48. Guérin, F.; Laville, A.; Daniellou, F.; Duraffourg, J.; Kerguelen, A. Understanding and Transforming Work the Pratice of Ergonomics and Transforming; ANACT: Lyon, France, 2006.

49. Rindova, V.P.; Martins, L.L. From Values to Value: Value Rationality and the Creation of Great Strategies. Strateg. Sci. 2018, 3, 323-334. [CrossRef]

50. Huxham, C.; Vangen, S. Researching organizational practice through action research: Case studies and design choices. Organ. Res. Methods 2003, 6, 383-403. [CrossRef]

51. Boog, B.; Keune, L.; Tromp, C. Editorial: Action research and emancipation. J. Community Appl. Soc. Psychol. 2003, 419-425. [CrossRef]

52. Thiollent, M. Metodologia da Pesquisa-Ação, 13th ed.; Cortez: São Paulo, Brazil, 2004.

53. Bradbury-Huang, H. What is good action research? Why the resurgent interest? Action Res. 2010, 8, 93-109. [CrossRef]

54. Cunningham, B. Action Research: Towards a Procedural Model. Hum. Relations 1976, 29, 215-238. [CrossRef]

55. Ottosson, S. Participation action research: A key to improved knowledge of management. Technovation 2003, 23, 87-94. [CrossRef]

56. Coghlan, D.; Brannick, T. Doing Action Research in Your Own Organization; SAGE: London, UK, 2010.

57. Coghlan, D. Organization development and action research: Then and now. In The Routledge Companion to Organizational Change; Boje, D., Burnes, B., Hassard, J., Eds.; Routledge: Abingdon, UK, 2012; pp. 46-58.

58. Hansen, H.P.; Nielsen, B.S.; Sriskandarajah, N.; Gunnarsson, E. Commons, Sustainability Basic, Democratization: Action Research and the Renewal of Society; Routledge: London, UK, 2016.

59. Parson, J.; Hewson, K.; Adrian, L.; Day, N. Engaging in Action Research: A Practical Guide to Teacher-Conducted Research for Educators and School Leaders; Brush Education: Edmonton, AB, Canada, 2013.

60. Coughlan, P.; Coghlan, D. Action research for operations management. Int. J. Oper. Prod. Manag. 2002, 22, 220-240. [CrossRef]

61. McArdle, K.; Reason, P. Action research and organization development. In Handbook of Organization Development; Cummings, T., Ed.; Sage: Thousand Oaks, CA, USA, 2008; pp. 123-136.

62. Ries, E. The Lean Startup: How Today's Entrepreneurs Use Continuous Innovation to Create Radically Successful Businesses; Crown Business: New York, NY, USA, 2011.

63. Cooper, B.; Vlaskovits, P. The Lean Entrepreneur: How Visionaries Create Products, Innovate with New Ventures, and Disrupt Markets; John Wiley \& Sons: Hoboken, NJ, USA, 2013.

64. Maurya, A. Running Lean: Iterate from Plan A to a Plan That Works, 2nd ed.; O'Reilly: Sebastopol, CA, USA, 2012.

65. Pink, M. Value Theory in the Economics of Sustainable Development. Probl. Ekorozw. Probl. Sustain. Dev. 2020, 15, 95-102.

66. Cambridge University Press Lemma “Capitalism”. Available online: http://dictionary.cambridge.org/dictionary/english/ capitalism (accessed on 25 March 2017).

67. Kahneman, D.; Tversky, A. Prospect Theory: An Analysis of Decision under Risk. Econometrica 1979, 47, 263-292. [CrossRef]

68. Agirreazkuenaga, L. Education for Agenda 2030: What Direction do We Want to Take Going Forward? Sustainability 2020, 12, $1-13$.

69. Milchram, C.; van de Kaa, G.; Doorn, N.; Künneke, R. Moral Values as Factors for Social Acceptance of Smart Grid Technologies. Sustainability 2018, 10, 2703. [CrossRef]

70. Voinea, C.L.; Logger, M.; Rauf, F.; Roijakkers, N. Drivers for Sustainable Business Models in Start-Ups: Multiple Case Studies. Sustainability 2019, 11, 1-25. 
71. LoMonaco-Benzing, R.; Ha-Brookshire, J. Sustainability as Social Contract: Textile and Apparel Professionals ' Value Conflicts within the Corporate Moral Responsibility Spectrum. Sustainability 2016, 8, 1278. [CrossRef]

72. Thatcher, A.; Yeow, P.H.P. A sustainable system of systems approach: A new HFE paradigm. Ergonomics 2016, 59, 167-178. [CrossRef] [PubMed]

73. Bolis, I.; Morioka, S.N.; Brunoro, C.M.; Zambroni-de-Souza, P.C.; Sznelwar, L.I. The centrality of workers to sustainability based on values: Exploring ergonomics to introduce new rationalities into decision-making processes. Appl. Ergon. 2020, $88,103148$. [CrossRef] [PubMed] 